\title{
IRRIGATION REQUIREMENTS OF FABA-BEAN UNDER TWO CLIMATIC LOCATIONS IN EGYPT
}

\author{
FAYED, T. B. 2; M. A. A. ABDRABBO ${ }^{1}$, MAHA M. A. HAMADA², \\ F. A. HASHEM ${ }^{1}$ and A. S. A.HEGAB ${ }^{1}$
}

1. Central Laboratory for Agricultural Climate (CLAC), ARC, Dokki, Egypt.

2. Department, Agronomy Faculty of Agric., Ain Shams Univ., Cairo, Egypt

(Manuscript received 22 October 2017)

\begin{abstract}
$\mathrm{T}$ wo field experiments were conducted in El-Bosaily farm, Behaira Governorate in the North Egypt (Delta region) and Dokki, Giza Governorate (Middle Egypt) during of 2011/2012 and 2012/2013 winter seasons to study the response of (Vicia faba L.,) Sakha3 faba bean cultivar to three irrigation water levels 0.60 , 0.80 and 1.00 of irrigation requirements (IR) applied by using drip irrigation system. The sowing date was in Mid Oct. in the two locations. Number of leaves per plant, number of branches per plant, leaf area index (LAI), total plant dry weight, biological and seed yields per plant and per feddan, seed carbohydrate and protein contents as well as water use efficiency (WUE) were determined. Vegetative growth traits as well as biological and seed yields of faba bean values were generally decreased at Dokki compared to El-Bosaily location. Meanwhile application of 0.60 of (IR) irrigation decreased the vegetative growth traits as well as biological and seed yields in the two locations. Nevertheless, the 1.00 irrigation treatment gave the greatest grain yield in the two locations compared to other irrigation levels. The final results showed that the 0.60 irrigation level gave the highest WUE value. Increasing irrigation water above 0.60 led to decrease WUE values. EL-Bosaily site gave the highest growth and productivity as well as higher WUE compared to Dokki location. Finally, the highest values of seed protein and carbohydrate contents in the faba bean were obtained from the lowest irrigation level (0.60 IR) at El-Bosaily farm during the two seasons.

Key words: Water use efficiency (WUE), v. faba, vegetative growth, seed yield, carbohydrate and protein percent.
\end{abstract}

\section{INTRODUCTION}

Faba bean (Vicia faba L.,) is considered one of the most important pulse crops in Egypt. It has become one of the most important strategic crops due to its net income to the farmers. Also, cultivation of faba bean is important for soil fertility, human nutrition and as a good source of protein, for animal feeding and industry purposes (Sharaan et al., 2004).

Irrigation level is one of the most important factors on crop productivity and quality. The vegetative growth and yield of faba bean declined when plants were imposed to water shortage (Moursi et al., 1976). Abd El-Mawgoud (2006) examined the impact of three irrigation levels $(80,100$ and $120 \%$ of class A-pan) on growth and 
productivity of green bean. Vegetative characters and yield components positively responded to increasing the irrigation level. Plant height, number of leaves, fresh and dry weights were increased with increasing irrigation rate. Alghamdi (2009) concluded that irrigation deficit increased protein content. On the other hand, El Afandi and Abdrabbo (2015) evaluated the reference evapotranspiration equations under current climate conditions of Egypt and found that Egypt is divided into three agro-climatic regions (Nile Delta in the north, middle and Upper Egypt) according to collected data of mean annual temperature and the reference evapotranspiration measurements (from 1998 to 2007). Also similar results were obtained by Abdrabbo et al. (2013) who reported that achieving greater water productivity is the primary challenge for scientists in agriculture. Therefore, changing irrigation schedule and using modern irrigation system could provide a cheap and easy way to implement irrigation management techniques.

Similar results were reported by Abdrabbo et al. (2016) who mentioned that the irrigation requirements increased depending on climatic region, Delta region has the lowest evapotranspiration during the studied period from 1998 to 2007 compared to Middle and Upper Egypt.

The aims of this investigation were to study the effect of climatic location and irrigation level on growth, yield components, seed yield and quality of faba bean. This to achieve best combination between irrigation level and location that can be recommended to the improve faba bean productivity under two agro-meteorological regions.

\section{MATERIAL AND METHODS}

Two experiments were carried out in two locations, first location was El- Bosaily, Protected Cultivation Experimental Farm, Behaira Governorate, North Egypt and the second was Dokki, Giza Governorate, Middle Egypt. The two locations belong to the Central Laboratory for Agricultural Climate (CLAC), Agricultural Research Center (ARC), Giza. The two experiments aimed to evaluate the effect of location, irrigation level and their interaction on growth and productivity of Sakha-3 faba bean cultivar. The sowing date was Mid Oct. in 2011/2012 and 2012/2013 seasons in the two locations.

Data in Table (1) illustrate the measured climatic factors i.e average air temperature ${ }^{\circ} \mathbf{C}$ (Ave. Temp.), average relative humidity percentage (Avg. RH),total precipitation(PREC) and evapotranspiration values during the experimental period (Mid Oct. till Mid March during 2011/2012 and 2012/2013 seasons). Data collected from automated weather stations of CLAC allocated at the experimental sites. 
The treatments comprised two locations (El-Bosaily and Dokki) and three irrigation levels ( $0.60,0.80$ and 1.00 of ETc). Estimation of irrigation levels were carried out based on the irrigation control done by manual valves for each experimental plot. The total quantity of irrigation water was calculated by Penman method (Penman, 1984). The potential evapotranspiration was calculated as follows:

$$
\begin{aligned}
& E T_{0}=C\{W \cdot R n(1-w)-F(u)(E a-E d)\} \\
& \mathrm{mm} / \text { day } \\
& \mathrm{ET}_{\mathrm{o}}=\text { Reference evapotranspiration }\left[\mathrm{mm} \mathrm{d}^{1}\right] \text {. } \\
& \mathrm{C}=\text { The adjustment factor (ratio of } \mathrm{U} \text { day to } \mathrm{U} \text { night). } \\
& \mathrm{Rn}=\text { Net radiation in equivalent evaporation expressed as } \mathrm{mm} / \text { day. } \\
& \mathrm{W}=\text { Temperature of altitude related factor. } \\
& F(U)=\text { Wind related function. } \\
& \text { Ea }- \text { ed= Vapour pressure deficit ( } m \text {. bar). } \\
& \mathrm{Ea}=\text { Saturated vapour pressure (m.bar). } \\
& E d=\text { Mean actual vapour pressure of the air (m. bar). }
\end{aligned}
$$

The second step was done to estimate values of crop water consumptive use (ETcrop) according to Doorenbos and Pruitt (1977):

The crop evapotranspiration, ETc, is calculated by multiplying the reference crop evapotranspiration, $\mathrm{ET}_{\mathrm{o}}$, by a crop coefficient, $\mathrm{K}_{\mathrm{c}}$ according to $\mathrm{FAO}$ (1998):

$$
\mathrm{IR}=\left(\mathrm{ET}_{\mathrm{o}} * \mathrm{~K}_{\mathrm{c}}\right)+\mathrm{LR} * 4.2 / \mathrm{Ea}
$$
( $\mathrm{m}^{3} /$ feddan/ day)

Where: -

$\mathrm{IR}=$ irrigation requirement for $\mathrm{crop}^{3} /$ feddan/ day

$\mathrm{K}_{\mathrm{c}}=$ Crop coefficient [dimensionless $]$.

$E \mathrm{~T}_{0}=$ Reference crop evapotranspiration [mm/day].

LR = Leaching requirement LR (\%) (assumed $20 \%$ of the total applied water).

Ea $=$ The efficiency of the irrigation system, (assumed $85 \%$ of the total applied water).

Table 1. A) Average monthly climatic data of the El-Bosaily and Dokki Sites during the two studied seasons of 2011/2012 and 2012/2013.

\begin{tabular}{|c|c|c|c|c|c|c|c|c|c|}
\hline \multicolumn{9}{|c|}{ Elbosaily } & \multicolumn{5}{c|}{ Dokki } \\
\hline Month & $\begin{array}{c}\text { Ave. } \\
\text { Temp. }\end{array}$ & RH\% & $\begin{array}{c}\text { Sum } \\
\text { PREC }\end{array}$ & ETo & Month & $\begin{array}{c}\text { 2011/2012 } \\
\text { Temp. }\end{array}$ & RH\% & $\begin{array}{c}\text { Sum } \\
\text { PREC }\end{array}$ & ETo \\
\hline Oct & 22.8 & 63 & 0 & 4.5 & Oct & 23.7 & 56.1 & 0.0 & 5.0 \\
\hline Nov & 15.9 & 67.5 & 0.2 & 2.3 & Nov & 16.5 & 60.1 & 0.1 & 2.6 \\
\hline Dec & 14.5 & 66.5 & 0.4 & 2.3 & Dec & 15.1 & 59.2 & 0.4 & 2.6 \\
\hline Jan & 12.2 & 66.5 & 1.1 & 2.6 & Jan & 12.7 & 59.2 & 0.9 & 2.9 \\
\hline Feb & 12.8 & 61.5 & 0.3 & 3.4 & Feb & 13.3 & 54.7 & 0.1 & 3.8 \\
\hline Mar & 15.2 & 63.5 & 0 & 4.2 & Mar & 15.8 & 56.5 & 0.0 & 4.6 \\
\hline \multicolumn{2}{|c|}{$\mathbf{2 0 1 2 / 2 0 1 3}$} & & & & \multicolumn{2}{|c|}{$\mathbf{2 0 1 2 / 2 0 1 3}$} & \\
\hline Oct & 23.2 & 67.5 & 0 & 4.1 & Oct & 24.1 & 60.1 & 0.0 & 4.5 \\
\hline Nov & 20.1 & 68.5 & 0 & 2.9 & Nov & 20.9 & 61.0 & 0.0 & 3.2 \\
\hline Dec & 15.5 & 64.5 & 29 & 2.6 & Dec & 16.1 & 57.4 & 21.2 & 3.0 \\
\hline Jan & 13.7 & 65.5 & 4.2 & 2.7 & Jan & 14.2 & 58.3 & 2.2 & 3.1 \\
\hline Feb & 14.9 & 66 & 0.1 & 3.3 & Feb & 15.4 & 58.7 & 0.0 & 3.5 \\
\hline Mar & 17.4 & 62 & 0 & 4.4 & Mar & 18.1 & 55.2 & 0.0 & 4.7 \\
\hline
\end{tabular}


Physical properties of the experimental soil were analyzed before sowing according to Chapman and Pratt (1961) and the results are tabulated in Table (2). The total amount of irrigation water was measured by water flow-meter for each irrigation treatment. Table (3) shows the seasonal irrigation water quantities for Sakha-3 cultivar under the different irrigation treatments at the two locations. Plants were irrigated by using drippers of $2 \mathrm{l} / \mathrm{hr}$ capacity. The chemical fertilizers were injected within irrigation water system (fertigation).

The permanent wilting point (PWP) and field capacity (FC) of the trial soil were determined according to Israelsen \& Hansen (1962).

Table 2. Some physical properties of the experimental soils at El-Bosaily and Dokki locations before cultivation.

\begin{tabular}{|c|c|c|c|c|c|c|c|c|}
\hline \multirow[b]{2}{*}{ Location } & \multirow{2}{*}{$\begin{array}{c}\text { Soil } \\
\text { depth } \\
\text { cm }\end{array}$} & \multicolumn{7}{|c|}{ Physical properties } \\
\hline & & $\begin{array}{c}\text { Sand } \\
\%\end{array}$ & $\begin{array}{c}\text { Clay } \\
\%\end{array}$ & Silt \% & Texture & FC \% & PWP \% & $\begin{array}{c}\text { Bulk density } \\
\mathrm{g} / \mathrm{cm}^{3}\end{array}$ \\
\hline El-Bosaily & $0-30$ & 95.31 & 4.30 & 0.36 & Sandy & 16.77 & 5.65 & 1.44 \\
\hline Dokki & $0-30$ & 10.4 & 64.4 & 25.2 & Clayey & 24.6 & 10.5 & 1.18 \\
\hline
\end{tabular}

The experiment was designed in a split plot arrangement with four replications. Locations were distributed in the main plots, and irrigation level were allocated in the sub plots. Sub-plot area was $15 \mathrm{~m}$ long $\times 3 \mathrm{~m}$ wide, occupying an area of $45 \mathrm{~m} 2$. Plants spaced $0.30 \mathrm{~m}$ apart; the distance between rows was $0.60 \mathrm{~m}$. A distance of $2 \mathrm{~m}$ was left as a border among the treatments.

All other agricultural practices of faba bean cultivation were done as recommended by the Ministry of Agriculture (MALR, 2013).

Samples of ten plants from each experimental plot were (randomly) taken to determine the following growth parameters 75 days after sowing, i.e. number of leaves and branches per plant, leaf area index (LAI), total plant fresh and dry weights (g/plant). At harvest weight of seeds/plant ( $\mathrm{g}$ ) as well as seed yield (ton/fed.) and biological yield (ton/fed.) were determined from each plot.

Table 3. Seasonal irrigation quantities ( $\mathrm{m}^{3} /$ fed.) under different water levels for Sakha3 faba bean cultivar under the two experimental conditions in ElBosaily and Dokki for 2011 /2012 and 2012/2013 seasons.

\begin{tabular}{|c|c|c|c|c|c|c|c|c|}
\hline \multirow{2}{*}{ Irrigation } & \multicolumn{9}{|c|}{$\mathbf{m}^{\mathbf{3}} /$ feddan } \\
\cline { 2 - 9 } & \multicolumn{3}{|c|}{$\mathbf{2 0 1 1 / 2 0 1 2} \mathbf{1}$} & \multicolumn{4}{c|}{$\mathbf{2 0 1 2 / 2 0 1 3}$} \\
\cline { 2 - 9 } & $\mathbf{6 0 \%}$ & $\mathbf{8 0 \%}$ & $\mathbf{1 0 0 \%}$ & Mean & $\mathbf{6 0 \%}$ & $\mathbf{8 0 \%}$ & $\mathbf{1 0 0 \%}$ & Mean \\
\hline El-Bosaily & 753 & 1004 & 1255 & 1004 & 772 & 1030 & 1287 & 1030 \\
\hline Dokki & 828 & 1104 & 1381 & 1104.4 & 849 & 1133 & 1416 & 1133 \\
\hline
\end{tabular}


The water use efficiency (WUE) was calculated according to FAO (1982) as follows: The ratio of crop yield $(Y)$ to the total amount of irrigation water use in the field for the growth season (IR); WUE $\left(\mathrm{kg} / \mathrm{m}^{3}\right)=\mathrm{Y}(\mathrm{kg}) / \mathrm{IR}\left(\mathrm{m}^{3}\right)$. Water use efficiency and seasonal water consumption were determined after harvest. Harvest was 120 days after sowing in both locations.

Plant samples were dried at $70{ }^{\circ} \mathrm{C}$ in an air forced oven for $48 \mathrm{~h}$. and total nitrogen was estimated in faba bean seeds by Kjeldahl method, according to Chapman and Pratt (1961). Total carbohydrate content was determined in seeds according to A.O.A.C. (2000).

Analysis of data was done, using SAS program for statistical analysis. The differences among means for all traits were tested at $5 \%$ level of propability according to Waller and Duncan (1969).

\section{RESULTS AND DISCUSSION}

\section{Effect of location and irrigation level on vegetative characters of faba bean plant}

Data presented in Table (4) show significant effects of location on all the studied vegetative characteristics in both seasons. First that, it is worthy to noting that leaf area index (LAI) values in the first season were higher than of the second season at the two locations. Differences in environmental conditions in the two seasons might be the reason for this finding. Results indicate that values of all faba bean vegetative growth traits i.e. number of leaves / plant, LAI, number of branches / plant and fresh and dry weights of total plant were higher under El-Bosaily conditions than those under Dokki. This finding was true in both 2011/2012 and 2012/2013 seasons. Climatic conditions prevailing at El-Bosaily location furnished favorable conditions to produce healthy and taller plants having greater LAI values and accumulated more dry matter during their duration cycle comparing with those of Dokki location plants.

The effect of irrigation levels on vegetative characters of faba bean were significant. Tables (4) showed that irrespective to locations, values of all the studied vegetative growth characters were significantly increased as irrigation water quantity increased. Therefore, the highest vegetative characters values were obtained by 1.00 (IR) followed by 0.80 (IR) during the two seasons whereas, the lowest values were achieved by 0.60 (IR) treatment in both seasons. Similar results were recorded by AlSuhaibani (2009) who reported that faba bean plants under higher water supply recorded higher number of leaves per plant and consequently higher leaf area per plant. Moreover, plants grown under water deficit conditions had less leaf area per plant to tolerate stress conditions by minimizing transpiration rate. Similar results on 
the deleterious impact of water stress on growth characteristics of faba bean plants was reported by Alderfasi and Alghamdi (2010).

With regard to the interaction effect between location and irrigation level, data showed that the best vegetative growth was obtained at El-Bosaily location combined with 1.00 (IR) during the both seasons. Whereas, the lowest values were obtained by Dokki location combined with 0.60 (IR) in two successive seasons. These results are in agreement with those mentioned by Sharaan et al (2004), Abd ElMawgoud (2006) and Abdrabbo et al (2016).

Table 4. Effect of location, irrigation level and their interaction on some of faba bean characters at El-Bosaily, Behira Governorate, and Dokki, Giza Governorate during 2011/2012 and 2012/2013 seasons.

\begin{tabular}{|c|c|c|c|c|c|c|c|c|}
\hline \multirow{3}{*}{ Locations } & \multicolumn{8}{|c|}{ Irrigation level (of IR) } \\
\hline & \multicolumn{4}{|c|}{ 2011/2012 } & \multicolumn{4}{|c|}{$2012 / 2013$} \\
\hline & 0.60 & 0.80 & 1.00 & Mean & 0.60 & 0.80 & 1.00 & Mean \\
\hline \multicolumn{9}{|c|}{ Number of leaves / plant } \\
\hline El-Bosaily & $33.0 \mathrm{e}$ & $41.7 \mathrm{c}$ & $50.1 \mathrm{a}$ & $41.3 \mathrm{~A}$ & $39.4 \mathrm{~d}$ & $46.0 \mathrm{~b}$ & $52.9 \mathrm{a}$ & $46.1 \mathrm{~A}$ \\
\hline Dokki & $28.9 \mathrm{f}$ & $37.0 \mathrm{~d}$ & $44.5 \mathrm{~b}$ & $36.8 \mathrm{~B}$ & $33.8 \mathrm{e}$ & $42.5 \mathrm{c}$ & $48.6 \mathrm{~b}$ & $41.6 \mathrm{~B}$ \\
\hline Mean & $30.9 \mathrm{C}$ & 38.9 B & 47.3 A & & $36.6 \mathrm{C}$ & 44.2 B & $50.7 \mathrm{~A}$ & \\
\hline \multicolumn{9}{|c|}{ Leaf area index (LAI) } \\
\hline El-Bosaily & $3.41 \mathrm{~d}$ & $5.09 \mathrm{~b}$ & $5.80 \mathrm{a}$ & $4.77 \mathrm{~A}$ & $2.93 \mathrm{~d}$ & $3.61 \mathrm{c}$ & $5.12 \mathrm{a}$ & $3.89 \mathrm{~A}$ \\
\hline Dokki & $2.84 \mathrm{e}$ & $4.20 \mathrm{c}$ & $5.35 b$ & $4.13 \mathrm{~B}$ & $2.37 \mathrm{e}$ & $3.19 \mathrm{~d}$ & $4.02 \mathrm{~b}$ & $3.19 \mathrm{~B}$ \\
\hline Mean & $3.13 \mathrm{C}$ & $4.64 \mathrm{~B}$ & $5.58 \mathrm{~A}$ & & $2.65 \mathrm{C}$ & $3.40 \mathrm{~B}$ & 4.57 A & \\
\hline \multicolumn{9}{|c|}{ Number of branches per plant } \\
\hline El-Bosaily & $4.30 \mathrm{~b}$ & $4.73 \mathrm{~b}$ & $5.39 a$ & $4.81 \mathrm{~A}$ & $3.32 \mathrm{e}$ & $4.02 \mathrm{c}$ & $5.31 \mathrm{a}$ & $4.22 \mathrm{~A}$ \\
\hline Dokki & $3.33 \mathrm{~d}$ & $3.90 \mathrm{c}$ & $4.48 \mathrm{~b}$ & $3.90 \mathrm{~B}$ & $2.92 \mathrm{f}$ & $3.67 \mathrm{~d}$ & $4.73 b$ & 3.77 A \\
\hline Mean & $3.82 \mathrm{C}$ & 4.31 B & $4.93 \mathrm{~A}$ & & $3.12 \mathrm{C}$ & $3.85 \mathrm{~B}$ & $5.02 \mathrm{~A}$ & \\
\hline \multicolumn{9}{|c|}{ Total plant fresh weight (g/plant) } \\
\hline El-Bosaily & $262 d$ & $309 \mathrm{~b}$ & 354 a & $308 \mathrm{~A}$ & 259 e & $310 \mathrm{c}$ & $377 a$ & 315 A \\
\hline Dokki & $215 \mathrm{e}$ & $273 c$ & $301 \mathrm{~b}$ & 263 B & $219 \mathrm{f}$ & $271 \mathrm{~d}$ & $322 \mathrm{~b}$ & $271 B$ \\
\hline Mean & $238 \mathrm{C}$ & 291 B & $327 \mathrm{~A}$ & & $239 \mathrm{C}$ & 291 B & 349 A & \\
\hline \multicolumn{9}{|c|}{ Total plant dry weight (g/plant) } \\
\hline El-Bosaily & $55.4 \mathrm{c}$ & $62.5 b$ & $73.9 \mathrm{a}$ & $63.9 \mathrm{~A}$ & $55.7 \mathrm{~d}$ & $69.5 \mathrm{~b}$ & $78.5 \mathrm{a}$ & $67.9 \mathrm{~A}$ \\
\hline Dokki & $47.9 \mathrm{~d}$ & $55.3 \mathrm{c}$ & $63.6 \mathrm{~b}$ & $55.6 \mathrm{~B}$ & $49.3 \mathrm{e}$ & $59.8 \mathrm{c}$ & $70.5 \mathrm{~b}$ & 59.9 B \\
\hline Mean & $51.6 \mathrm{C}$ & 58.9 B & $68.7 \mathrm{~A}$ & & $52.5 \mathrm{C}$ & $64.6 \mathrm{~B}$ & $74.5 \mathrm{~A}$ & \\
\hline
\end{tabular}




\section{Effect of location and irrigation level on biological and seed yields}

The effect of different locations and irrigation levels on values of faba bean seeds weight per plant, and seed and biological yields were presented in Table (5).

Differences between the two locations with regard to weight of seeds per plant, seed yield and biological yield /fed. were significant. El-Bosaily location gave higher values of all traits. Superiority of El-Bosaily location in this respect may have resulted from the obvious increase in vegetative growth traits i.e. LAI, number of branches, number of leaves, fresh weight and total plant dry weight (Table 4).

Referring the effect of different irrigation levels, data showed that productivity criteria were increased as irrigation water quantity increased. Using 1.00 (IR) recorded the highest values of faba bean biological and seed yields followed by 0.80 (IR) during in the two seasons. Low irrigation level (0.6 IR) decreased biological and seed yields. Interpretation of such findings were reported by Erdem et al., (2006) who stated that adequate moisture availability in soil lead to increase of various physiological processes, better nutrients uptake, higher rate of photosynthesis which might be reflected on more number and area of leaves and higher yields. Similar results were observed by Abd El-Mawgoud (2006).

Regarding the interaction effect between locations and irrigation levels, data in Table (5) showed that the highest values of faba bean seed and biological yields were obtained at El-Bosaily location for 1.00 (IR). On the other hand, the lowest seed and biological yields were recorded at Dokki location for 0.60 (IR) during the two seasons.

Table 5. Effect of locations and irrigation levels on faba bean seed weight per plant, seed yield per feddan and biological yield at El-Bosaily, Behira Governorate, and Dokki Giza Governorate during 2011/2012 and 2012/2013 seasons.

\begin{tabular}{|c|c|c|c|c|c|c|c|c|}
\hline \multirow{3}{*}{ Locations } & \multicolumn{8}{|c|}{ Irrigation levels (of IR) } \\
\hline & \multicolumn{4}{|c|}{$2011 / 2012$} & \multicolumn{4}{|c|}{$2012 / 2013$} \\
\hline & 0.60 & 0.80 & 1.00 & Mean & 0.60 & 0.80 & 1.00 & Mean \\
\hline \multicolumn{9}{|c|}{ Weight of seeds per plant (g) } \\
\hline $\begin{array}{c}\text { El- } \\
\text { Bosaily }\end{array}$ & $65.3 \mathrm{~d}$ & $70.5 \mathrm{c}$ & $87.0 \mathrm{a}$ & $74.3 \mathrm{~A}$ & $75.2 \mathrm{e}$ & $86.2 \mathrm{c}$ & $103 a$ & $88.2 \mathrm{~A}$ \\
\hline Dokki & $59.4 \mathrm{e}$ & $65.3 d$ & $76.3 \mathrm{~b}$ & $67.0 \mathrm{~B}$ & $67.0 \mathrm{f}$ & $79.7 \mathrm{~d}$ & $91.3 \mathrm{~b}$ & 79.4 B \\
\hline Mean & $62.4 \mathrm{C}$ & $67.9 \mathrm{~B}$ & $81.6 \mathrm{~A}$ & & $71.1 \mathrm{C}$ & $83.0 \mathrm{~B}$ & $97.3 \mathrm{~A}$ & \\
\hline \multicolumn{9}{|c|}{ Seed yield (ton/fed.) } \\
\hline $\begin{array}{c}\text { El- } \\
\text { Bosaily }\end{array}$ & $1.18 \mathrm{~b}$ & $1.41 \mathrm{a}$ & $1.43 \mathrm{a}$ & $1.34 \mathrm{~A}$ & $1.24 \mathrm{c}$ & $1.35 \mathrm{~b}$ & $1.60 \mathrm{a}$ & $1.40 \mathrm{~A}$ \\
\hline Dokki & $1.03 \mathrm{c}$ & $1.19 \mathrm{~b}$ & $1.22 \mathrm{~b}$ & $1.15 \mathrm{~B}$ & $1.06 \mathrm{~d}$ & $1.16 \mathrm{c}$ & $1.34 \mathrm{~b}$ & $1.18 \mathrm{~B}$ \\
\hline Mean & $1.11 \mathrm{~B}$ & $1.30 \mathrm{~A}$ & $1.32 \mathrm{~A}$ & & $1.15 \mathrm{C}$ & $1.25 \mathrm{~B}$ & $1.47 \mathrm{~A}$ & \\
\hline \multicolumn{9}{|c|}{ Biological yield (ton/fed) } \\
\hline $\begin{array}{c}\text { El- } \\
\text { Bosaily }\end{array}$ & $1.36 \mathrm{~d}$ & $1.70 \mathrm{~b}$ & $1.99 \mathrm{a}$ & $1.68 \mathrm{~A}$ & $1.62 \mathrm{~b}$ & $1.65 \mathrm{~b}$ & $1.77 \mathrm{a}$ & $1.68 \mathrm{~A}$ \\
\hline Dokki & $1.28 \mathrm{~d}$ & $1.52 \mathrm{c}$ & $1.77 \mathrm{~b}$ & $1.52 \mathrm{~B}$ & $1.40 \mathrm{~d}$ & $1.46 \mathrm{c}$ & $1.57 \mathrm{bc}$ & $1.48 \mathrm{~B}$ \\
\hline Mean & $1.32 \mathrm{C}$ & $1.61 \mathrm{~B}$ & $1.88 \mathrm{~A}$ & & $1.51 \mathrm{~B}$ & $1.55 \mathrm{~B}$ & $1.67 \mathrm{~A}$ & \\
\hline
\end{tabular}




\section{Effect of location and irrigation level on seed carbohydrate and seed protein percentage}

Carbohydrate and protein percentages in faba bean seeds were significantly affected by studied treatments (Table 6). El-Bosaily location gave higher values of seed carbohydrate and protein compared with those of Dokki ones.

Concerning the effect of irrigation level, data showed that increasing irrigation level led to a gradual reduction in carbohydrate and protein percentages up to 1.00 IR. Therefore, the lowest carbohydrate and protein percentages were obtained from 1.00 irrigation level in the two seasons. These findings could be due to that protein is considered a good indicator for plant tolerance to water deficit, since adequate water supply caused hydrolysis and catabolism in proteins and releasing free amino acids and ammonia as well as proline (Fayed, 1972).

Regarding the effect of interaction between different location and irrigation level, data showed that the highest carbohydrate and protein percentages were obtained at El-Bosaily location at 0.60 irrigation level. On the other hand, the lowest carbohydrate and protein percentages were obtained at Dokki location for 1.00 irrigation treatment in the two seasons.

Table 6. Effect of location, irrigation level and their interaction on seed carbohydrate and protein percentage of faba bean at El-Bosaily, Behira Governorate, and Dokki, Giza Governorate during 2011/2012 and 2012/2013 seasons.

\begin{tabular}{|c|c|c|c|c|c|c|c|c|}
\hline \multicolumn{9}{|c|}{ Carbohydrate (\%) } \\
\hline El-Bosaily & $41.3 \mathrm{a}$ & $39.6 \mathrm{~b}$ & $33.9 \mathrm{~d}$ & $38.3 \mathrm{~A}$ & 49.9 a & $49.6 \mathrm{a}$ & $42.1 \mathrm{~d}$ & 47.2 A \\
\hline Dokki & $35.9 \mathrm{c}$ & $34.5 d$ & $30.8 \mathrm{e}$ & 33.7 B & $44.6 \mathrm{~b}$ & $43.0 \mathrm{c}$ & $40.3 \mathrm{e}$ & 42.6 B \\
\hline Mean & $38.6 \mathrm{~A}$ & $37.0 \mathrm{~B}$ & $32.3 \mathrm{C}$ & & $47.2 \mathrm{~A}$ & $46.3 \mathrm{~A}$ & $41.2 \mathrm{~B}$ & \\
\hline \multicolumn{9}{|c|}{ Protein (\%) } \\
\hline El-Bosaily & $31.0 \mathrm{a}$ & $28.7 \mathrm{~b}$ & $26.9 c$ & 28.9 A & $29.2 \mathrm{a}$ & $29.0 \mathrm{~b}$ & $26.2 \mathrm{c}$ & $28.1 \mathrm{~A}$ \\
\hline Dokki & $27.6 \mathrm{c}$ & $25.3 d$ & $23.7 \mathrm{e}$ & 25.5 B & $26.0 \mathrm{c}$ & $25.8 \mathrm{c}$ & $24.1 \mathrm{~d}$ & $25.3 \mathrm{~B}$ \\
\hline Mean & $29.3 \mathrm{~A}$ & $27.0 \mathrm{~B}$ & $25.3 \mathrm{C}$ & & $27.6 \mathrm{~A}$ & $27.4 \mathrm{~A}$ & 25.1 B & \\
\hline
\end{tabular}

\section{Effect of location and irrigation level on water use efficiency (WUE)}

The effect of location, irrigation level and their interaction on water use efficiency (WUE) $\mathrm{kg} / \mathrm{m}^{3}$ of faba bean is shown in Table (7). It is revealed that locations affected values of water use efficiency in the two seasons. El-Bosaily location recorded higher WUE values compared with Dokki location. Variation between the two locations in climatic assessments (Table 1) and seasonal irrigation quantities requirement (Table 3 ) as well as faba bean seed yield (Table 5) may account much for this finding.Water use efficiency (WUE) values of faba bean were significantly responded to irrigation water quantities. Increasing irrigation quantity gradually 
decreasedWUE values in both experimental seasons. Thereby, the highest WUE value was achieved from 0.60 (IR) irrigation level treatment.

The effect of location irrigation level interaction on WUE value was also significant (Table 7). However, El-Bosaily location combined with 0.60 (IR) had the highest WUE compared to other treatments. The lowest WUE was obtained by Dokki location combined with 1.00 (IR) treatment in the two seasons. These data agreed with those obtained by Alderfasi and Alghamedi (2010) and El Afandi and Abdrabbo (2015) who concluded that WUE in the Delta was higher than those of Middle and Upper Egypt because Delta region need lower irrigation quantity based on meteorological study for different climatic regions in Egypt.

Table 7. Effect of location, irrigation level and their interaction on water use efficiency $\left(\mathrm{kg} / \mathrm{m}^{3}\right)$ of faba bean at El-Bosaily, Behira Governorate, and Dokki Giza Governorate during 2011/2012 and 2012/2013 seasons.

\begin{tabular}{|c|c|c|c|c|c|c|c|c|}
\hline \multirow{3}{*}{$\begin{array}{l}\text { Diferent } \\
\text { Location } \\
\text { s }\end{array}$} & \multicolumn{8}{|c|}{ Irrigation levels (of IR) } \\
\hline & \multicolumn{4}{|c|}{$2011 / 2012$} & \multicolumn{4}{|c|}{$2012 / 2013$} \\
\hline & 0.60 & 0.80 & 1.00 & Mean & 0.60 & 0.80 & 1.00 & Mean \\
\hline \multicolumn{9}{|c|}{ Water use efficiency $(\mathrm{kg} / \mathrm{m} 3)$} \\
\hline $\begin{array}{c}\text { El- } \\
\text { Bosaily }\end{array}$ & $1.42 \mathrm{a}$ & $1.27 \mathrm{~b}$ & $1.03 \mathrm{c}$ & $1.24 \mathrm{~A}$ & $1.53 \mathrm{a}$ & $1.25 \mathrm{c}$ & $1.19 \mathrm{c}$ & $1.32 \mathrm{~A}$ \\
\hline Dokki & $1.30 \mathrm{~b}$ & $1.12 \mathrm{c}$ & $0.92 \mathrm{~d}$ & $1.11 \mathrm{~B}$ & $1.37 \mathrm{~b}$ & $1.13 \mathrm{c}$ & $1.02 \mathrm{~d}$ & $1.17 \mathrm{~B}$ \\
\hline Mean & $1.36 \mathrm{~A}$ & $1.19 \mathrm{~B}$ & $0.98 \mathrm{C}$ & & $1.45 \mathrm{~A}$ & $1.19 \mathrm{~B}$ & $1.11 \mathrm{~B}$ & \\
\hline
\end{tabular}

\section{CONCLUSION}

Increasing water productivity is a major goal in modern agriculture to maintain food security and agriculture sustainability. In general, 0.60 irrigation level accompanied with El-Bosaily location in North Egypt was the best combination for faba bean aimed at maximal WUE in this study. This conclusion is slightly different from our results aiming at higher seed yield obtained by $100 \%$ irrigation level. The adoption of 0.6 irrigation level will be superior to 1.00 irrigation level if the irrigation water is a limiting factor or the farmer facing water scarcity. Moreover, cultivation of strategic crops in the Delta improves the water productivity than Middle Egypt. Further studies related to test more faba bean varieties need to be conducted to increase the knowledge about the productivity of faba bean under different climatic regions by using drip irrigation system. 


\section{REFERENCES}

1. A.O.A.C. 2000. Official Methods of Analysis of the Association of Official Analytical Chemists. $11^{\text {th }}$ edition. Washington D.C., USA

2. Abd El-Mawgoud, A.M.R 2006. Growth, yield and quality of green bean (Phaseolus vulgaris) in response to irrigation and compost applications. J. Appl. Sci., 2(7), 443-450.

3. Abdrabbo, M. A. A.; HashemF. A.andAbou-Hadid A. F. 2016.Irrigation requirements for some bread wheat cultivars in relation to planting dates. Journal of Agricultural Science and Research (JASR) Vol. 3, Issue 1, Jun 2016, 23-40 .

4. Abdrabbo, M. A. A.;OudaS., and Noreldin, T. 2013. Modeling the irrigation schedule on wheat under climate change conditions. Nature and Science. 11 (5): 10-18.

5. Alderfasi A.A. and Alghamdi S.S. 2010. Integrated water supply with nutrient requirements on growth, photosynthesis productivity, chemical status and seed yield of faba bean. Amri-Eur J. Agron, 3 (1), 08-17.

6. Alghamdi, S. S. 2009. Chemical composition of faba bean (Vicia faba L.), genotypes under various water regimes. Pak. J. Nutr.، 8 (4): 477-482.

7. Al-Suhaibani N.A. 2009. Influence of early water deficit on seed yield and quality of faba bean under arid environment of Saudi Arabia. Amri-Eur J. Agric. \& Environ. Sci., 5 (5), 649-654.

8. Chapman, H. D. and Pratt F. 1961. Methods of Analysis for Soils, Plants and Water. Univ. Calif., 35:6-7.

9. Doorenbos, J. and W. O. Pruitt. 1977. Guidelines for predicting crop water requirements. Irrigation and drainage paper, FAO, Rome, No. 24 pp. 144.

10. El Afandi, G. and Abdrabbo, M. A. A. 2015.Evaluation of reference evapotranspiration equations under current climate conditions of egypt. Turkish Journal of Agriculture - Food Science and Technology, 3(10): 819-825.

11. Erdem Y; Seshril S.; Erdem T. and Kenar D. 2006. Determination of crop water stress index for irrigation scheduling of bean (Phaseolus vulgaris L.). . Turk J Agric. 30: 195-202..

12. FAO.(1982). Crop water requirements irrigation and drainage. Paper No. 24, Rome Italy

13. FAO. 1998. Crop Evapotranspiration: Guide Lines for Computing Crop Water Requirements. By: Richard Allen, Luis Pereira، Dirk Raes and Martin Smith. FAO Irrigation and Drainage Paper 56. Rome, Italy. 
14. Fayed, M.T.B. 1972. Persistence of simazine and its effects on the common weeds grown in corn field. Ph.D.Thesis, Agron. Dept., Fac. Agric., Ain Shams Univ. Egypt.164

15. Israelsen, B.O. and Hansen V.E. 1962. Irrigation Principles and Practices $3^{\text {rd }}$ Edit. John Wiley and Sons Inc, New York.USA

16. MALR. 2013. Cultivation and management faba bean. Bulettien No (1301), 1-20.

17. Moursi, M.A.; El-Habbasha, K.M. and Shaheen, A.M. 1976. Photosynthetic efficiency. Water and nitrogen contents of Vicia faba plant as influenced by water deficit. Egypt. J. Agron. 1(2), 238-246.

18. Penman, H. L. 1984. Natural evaporation from open water, bare soil and grass Proceedings Royal Society of London, Series, 193:120-146.

19. Sharaan, A.N; Ekram A.; Megawer H.A.S. and Hemida Z.A. 2004. Seed yield, yield components and quality character as affected by cultivars, sowing dates and planting distances in faba bean. Bull. Agric. Econ. Min. Agric. Egypt. http://fayoum.edu.eg/Agriculture/Crops/pdf/Fabapaper3.pdf

20. Waller, R. A. and Duncan D. B. 1969. A bayes rule for the symmetric multiple comparison problem, J. Am. Stat. Assoc 64, 1484-1504. 
"الإحتياجات الإرو ائية للفول البلاى تحت ظروف إقليمين مناخيين فى مصر"

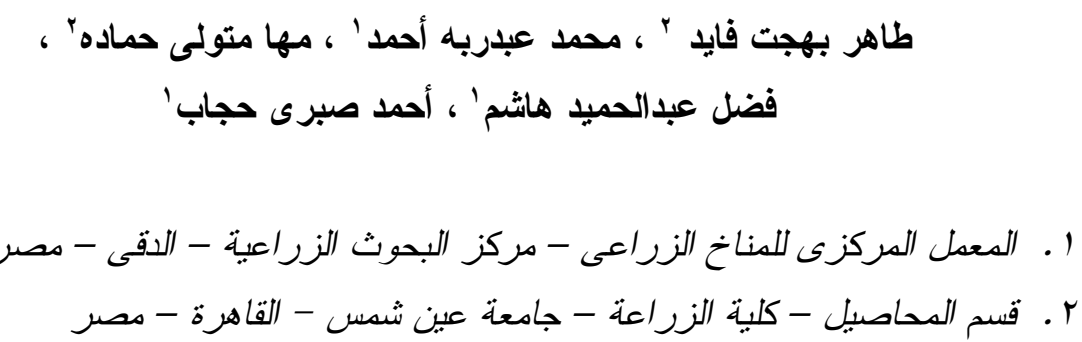

أجريت تجربتنن حقليتين الاولى في مزرعة البوصيلي بمحافظة البحيرة (منطقة الدلثا) و الثانية

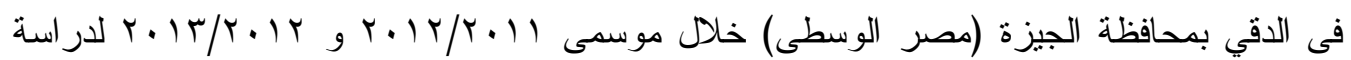

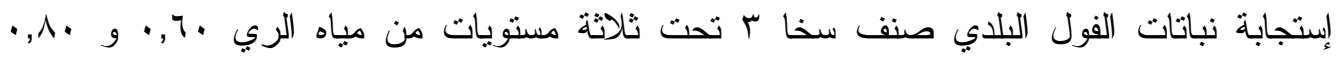

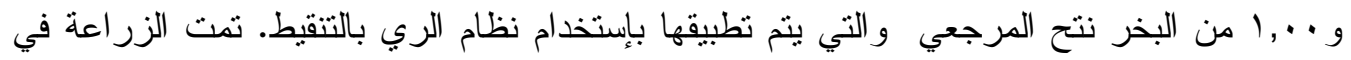

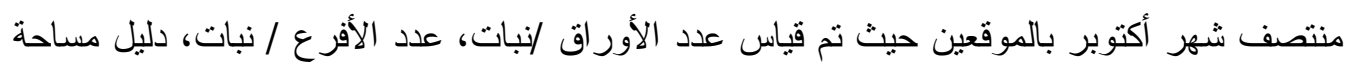

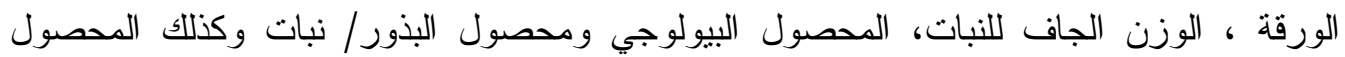

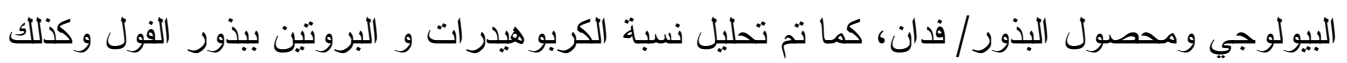

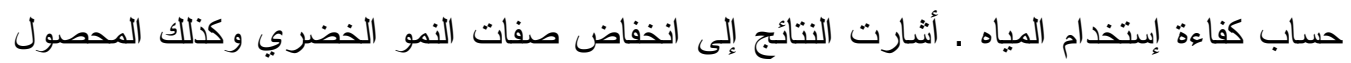

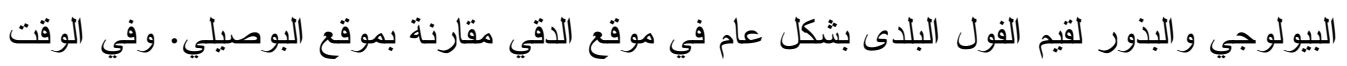

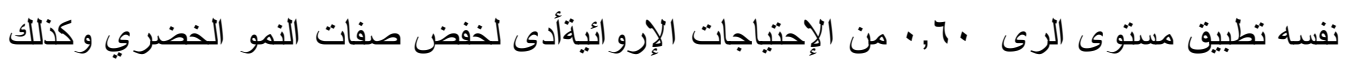

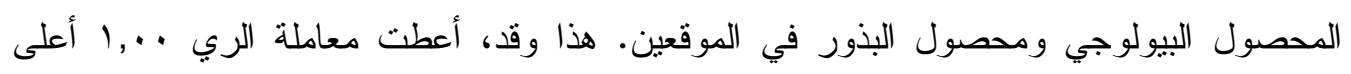

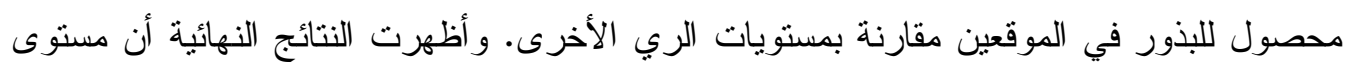

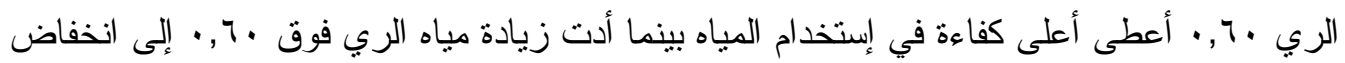

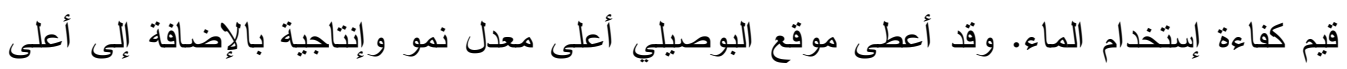

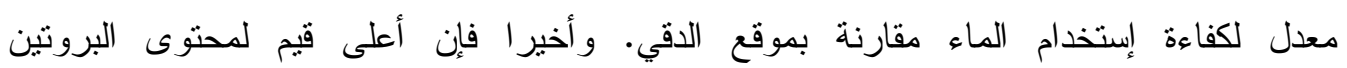

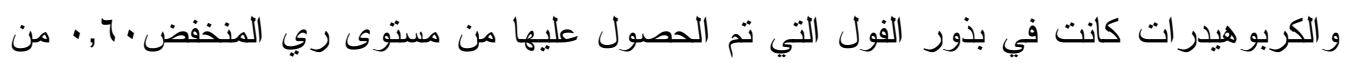

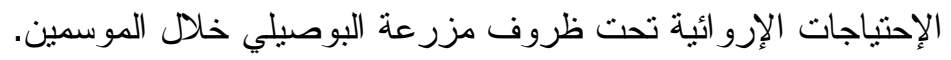

